\title{
Keeping Religious Fundamentalism Under Wraps: The Clothing Controversy in Selected European COUNTRIES
}

\author{
Richard W. Bauman and Sarah L.M. Weingarten*
}

\section{INTRODUCTION}

The passage by the French government in March 2004 of a law prohibiting the conspicuous display of religious symbols and the wearing of religious apparel by students enrolled in public schools caused considerable controversy, not only within France, but in other quarters as well, for the law stopped female students affiliated with Islam from wearing religious headscarves. Muslim groups both inside and outside France responded critically. Among the notorious repercussions of this law was the subsequent kidnapping in Iraq of two French journalists. ${ }^{1}$ Somewhat less publicized (but equally important) events in the past year have been decisions by European courts arising out of human rights challenges to similar bans made in Turkey and in the U.K. - that apply to students' attire when attending public schools or universities. ${ }^{2}$ In this instance, multicultural values

\footnotetext{
Support for the research and writing of this article was provided by SSHRC, project number G124130370.

The kidnapping on 20 August 2004 of Georges Malbrunot of $L e$ Figaro and Christian Chesnot of Radio France Internationale was accompanied by threats to kill them if the new law, due to take effect at the beginning of the school term in France, was not repealed. See Elaine Sciolino, "Hostages Urge France to Repeal Its Scarf Ban" New York Times (31 August 2004) A8. Although several deadlines were given and the French government refused to meet them, the hostages survived. They were released on 21 December 2004. For a chronology of events, see “Dossiers d'actualité: Libération de Christian Chesnot et Georges Malbrunot en Irak" (France: Ministère des Affaires étrangères, 2004), online: <http://www.diplomatie. gouv.fr/actu/article.asp?ART $=44107>$.

It should be noted that the cases and legislative initiatives that we will be discussing represent only a few recent examples of the manifestation of ongoing and widespread conflict over the proper role of religion, culture, and symbols related thereto in contemporary Europe. There have been other regional court cases dealing with the same or similar issues. For discussion, see, for example, Axel Frhr. von Campenhausen, "The German
}

that would encourage students to display their religious commitments are subordinated. They must take second place to several European governments' goal of promoting a strictly secular educational environment.

Such restrictions have been challenged legally. Judicial review of rules regarding clothing must take into account the rights and freedoms contained in the European Convention on Human Rights $^{3}$ and in particular freedom of religion, enshrined in Article 9 of the Convention. The cases discussed below extend our understanding of how courts will interpret the guarantees contained in Article 9. Ultimately, whether a law or regulation is constitutionally valid depends crucially on the specific historical and social context of the European country in question. Courts will examine the circumstances under which the impugned law (and any violation of the right to religious freedom) is justified as necessary. The judges will inquire into the purposes of the law and how it furthers democratic

Headscarf Debate" (2004) 2004 Brigham Young University Law Review 665. For a very interesting discussion of religious and other cultural identities and points of conflict with other European and liberal values in Norway, see Unni Wikan, Generous Betrayal: Politics of Culture in the New Europe (Chicago: University of Chicago Press, 2002) [Wikan].

Convention for the Protection of Human Rights and Fundamental Freedoms, 4 November 1950, 213 U.N.T.S. 221, Eur. T.S. 5 [ECHR], online: European Court of Human Rights $<$ http://www.echr.coe.int/Convention/webConvenENG.pdf $>$ [European Convention]. 
goals. ${ }^{4}$ To this extent, there is no single European standard governing the constitutionality of laws on religious clothing. Whether a law is valid, even though it interferes with religious freedom, depends crucially on the particular conditions present in the country where the law is adopted. The difference in the respective demographics and histories of Turkey, the U.K., and France, in regard to the separation of political life from religious beliefs and institutions, plays out in the materials we examine below.

We propose to look at these recent European developments, to set them against the background of judicial precedents interpreting Article 9, to indicate some of the salient features of the reasoning by courts and legislatures, and to conclude by sifting out some important lessons about the current situation in Europe regarding the relations between states and religions.

\section{ARTICLE 9 OF THE EUROPEAN CONVENTION}

Recent cases concerning religious attire focus on Article 9 of the European Convention..$^{5}$ Therefore, it is worth noting at the outset the content of the section and the general approach that courts (in particular the European Court of Human Rights) have taken to its interpretation. Article 9 itself reads as follows:

\section{ARTICLE 9 - FREEDOM OF THOUght, CONSCIENCE AND RELIGION}

1 Everyone has the right to freedom of

\footnotetext{
For readers conversant with Canadian constitutional law, it is worthwhile pointing out that, under the structure of Article 9 , the court need not emphasize "proportionality" as a separate requirement in the way that a Canadian court would in assessing a potential reasonable limit under s. 1 of the Canadian Charter of Rights and Freedoms, Part I of the Constitution Act, 1982, being Schedule B to the Canada Act 1982 (U.K.), 1982, c. 11. Although proportionality is a consideration that the European Court of Human Rights (ECHR) has taken into account in consideration of Art. 9, and indeed given significant weight, it is not a free-standing requirement and has at times been subsumed into the Court's overall analysis of reasonableness. For discussion of the use of proportionality as an interpretive principle with respect to Article 9, see David Kinley, "Legal Rights and State Responsibilities under the ECHR" in Linda Hancock \& Carolyn O'Brien, eds., Rewriting Rights in Europe (Aldershot: Ashgate, 2000) 151 at 162.

Supra note 3
}

thought, conscience and religion; this right includes freedom to change his religion or belief and freedom, either alone or in community with others and in public or private, to manifest his religion or belief, in worship, teaching, practice and observance.

2 Freedom to manifest one's religion or beliefs shall be subject only to such limitations as are prescribed by law and are necessary in a democratic society in the interests of public safety, for the protection of public order, health or morals, or for the protection of the rights and freedoms of others.

Kokkinakis v. Greece $e^{6}$ provides the leading discussion of the basis for the section and of its significance. In that case, the European Court of Human Rights (ECHR) stated as follows:

As enshrined in Article 9 ... freedom of thought, conscience and religion is one of the foundations of a "democratic society" within the meaning of the Convention. It is, in its religious dimension, one of the most vital elements that go to make up the identity of believers and their conception of life, but it is also a precious asset for atheists, agnostics, sceptics and the unconcerned. The pluralism indissociable from a democratic society, which has been dearly won over the centuries, depends on it. ${ }^{7}$

Based on the language of Article 9, there are several elements that a court must consider in assessing a claim under the section. More specifically, the analytical process of the Court should be as follows, as summarized in the leading

Kokkinakis v. Greece (1994), 17 E.H.R.R. 397, no. 14307/88, ECHR, 1994, online: European Court of Human Rights <http:// cmiskp.echr.coe.int/tkp197/search.asp?skin=hudocen $>$ [Kokkinakis]. It should be noted that the Kokkinakis decision includes several additional concurring and dissenting judgments along with the main judgment; these reflect some divergence of opinion on the proper way to interpret Article 9. We will restrict our discussion to the majority view.

Ibid. at para. 31 . 
case of Şahin v. Turkey: ${ }^{8}$

The Court must consider whether the applicant's right under Article 9 was interfered with and, if so, whether such interference was "prescribed by law," pursued a legitimate aim and was "necessary in a democratic society" within the meaning of Article $9 \S 2$ of the Convention. ${ }^{9}$

In proceeding through these analytical steps, courts are guided by a number of leading decisions. The first step is for the Court to determine whether or not there has been a violation of the rights guaranteed in Article 9(1). Cases dealing with religious attire, among others, have focused particularly on the enumerated right to manifest religion and belief. ${ }^{10}$ In Kokkinakis, this right was briefly discussed. The ECHR stated that the right to bear witness to one's religion through religious manifestation was a right implied by religious freedom and "bound up with the existence of religious convictions." ${ }^{11}$ However, despite the importance accorded freedom to manifest one's religion, it should be noted that Article 9(1) has not been interpreted to cover every action inspired by religious belief, nor does it permit unlimited action based on religious belief in the public sphere. ${ }^{12}$

Besides these general principles, the analysis of whether or not Article 9(1) has been violated tends to be fact-specific. In order to establish the context for recent decisions regarding religious attire, it should be noted that there is authority to the effect that certain limitations on wearing religious dress, and in particular headscarves, constitute a violation of Article 9(1). ${ }^{13}$ This

Şahin v. Turkey, no. 44774/98, ECHR, 2004, online: European Court of Human Rights <http://cmiskp.echr.coe.int/tkp197/ search.asp? skin=hudoc-en $>$ [Şahin]. This case will be discussed in further detail below.

Ibid. at para. 67.

10 For discussion of the right to manifest one's religion, see for example: Peter W. Edge, "Current Problems in Article 9 of the European Convention on Human Rights" (1996) Juridical Review 42 at 45 .

Supra note 6 at para. 31 .

Şahin, supra note 8 at para. 66.

3 See for a notable example: Dahlab v. Switzerland, no 42393/98, ECHR, 2001, online: European Court of Human Rights <http://cmiskp.echr.coe.int/tkp197/search.asp?skin= hudoc-en $>[$ Dahlab]; see also Karaduman v. Turkey, no. approach has been reflected in more recent cases (as will be discussed below), such that generally, much of the analysis in these recent cases dealing with religious attire focuses on potential justification under Article 9(2).

In the case of a violation of rights under Article 9(1), the next step is to determine if the violation is justified under Article 9(2), which requires the violation to be: (a) prescribed by law, (b) in pursuance of a legitimate state objective, and (c) necessary (with respect to enumerated purposes). ${ }^{14}$ The general purpose of Article 9(2), per Kokkinakis, is to recognize "that in democratic societies, in which several religions coexist within one and the same population, it may be necessary to place restrictions on this freedom in order to reconcile the interests of the various groups and ensure that everyone's beliefs are respected." 15

The first requirement under Article 9(2) is that any limitation on the religious rights in Article 9(1) be "prescribed by law." This requirement is discussed in a number of cases, including Hasan v. Bulgaria,${ }^{16}$ Rotaru v. Romania,${ }^{17}$ and Şahin, which reveal a set of key principles. Firstly, per Rotaru, "the expression 'in accordance with the law' not only requires that the impugned measure should have some basis in domestic law, but also refers to the quality of the law in question, requiring that it should be accessible to the person concerned and foreseeable as to its effects. ${ }^{~} 18$ In other words, the language "prescribed by law" is intended to connote a fair notice requirement, so that the law is sufficiently accessible and

16278/90, ECHR, 1993, cited in Şahin, ibid. at para. 98.

14 It is worth noting that this formulation of Art. 9(2) was one of the less broad formulations of those originally considered. Other suggested versions of Art. 9(2) included reference to historical justifications of importance to the state, but the language was ultimately drafted so as to be more consistent with the justification clauses in other articles. See, for discussion and examples of alternative versions of the text, J.E.S. Fawcett, The Application of the European Convention of Human Rights (Oxford: Clarendon Press, 1987) at 236-37.

15 Supra note 6 at para. 33

16 Hasan v. Bulgaria (2000) 10 B.H.R.C. 646 (Eur. Ct H.R.), online: European Court of Human Rights <http://cmiskp.echr. coe.int/tkp197/search.asp?skin=hudoc-en $>$ [Hasan]. We will return to this point below.

17 Rotaru v. Romania, no. 28341/95, ECHR, 2000-V, online: European Court of Human Rights <http://cmiskp.echr.coe. int $/$ tkp 197/view .asp? item $=1 \&$ portal $=\mathrm{hbkm} \&$ action $=\mathrm{htm} 1 \& \mathrm{hi}$ ghlight $=$ rotaru $\&$ sessionid $=281932 \&$ skin $=$ hudoc - en $>[$ Rotaru $]$.

18 Ibid. at para. 52 [citations omitted]. 
foreseeable to allow affected individuals to regulate their conduct. ${ }^{19}$ Article 9(2) requires clear formulation of any discretion encompassed by a given law, reflecting that the language is also designed to protect the rule of law by preventing abuses of rights based on unfettered discretion. ${ }^{20}$ Secondly, although the law requires clarity and fair notice, some degree of vagueness may be permissible, in light of the facts that statutory language can be vague and that some laws are necessarily more precise than others. ${ }^{21}$ Lastly, the term "law" is fairly broad, including both statutes and common law. ${ }^{22}$

The second requirement under Article 9(2) is that the limitation on religious rights pursues a legitimate state aim. The cases are less helpful in clarifying this requirement, providing little by way of guiding principle. However, it is worth noting that at least one case considers the justification of state aims with reference to the enumerated considerations in Article 9(2) (that is, public health, safety, order, and the protection of the rights of others). ${ }^{23}$ This suggests that these considerations may be relevant to the requirement of a legitimate state aim, as well as the requirement of necessity.

The final requirement under Article 9(2) is that the limitation on religious rights be "necessary." The leading case on the necessity requirement appears to be Dahlab v. Switzerland, ${ }^{24}$ which states:

Lastly, as to whether the measure was "necessary in a democratic society," the Court reiterates that, according to its settled caselaw, the Contracting States have a certain margin of appreciation in assessing the existence and extent of the need for interference, but this margin is subject to European supervision, embracing both the law and the decisions applying it, even those given by

\footnotetext{
19 Hasan, supra note 16 at para. 84. See also Rotaru, supra note 17 at para. 55 .

Hasan, ibid.

21 Kokkinakis, supra note 6 at para. 40

22 Sahin, supra note 8 at para. 77. More precisely: "the 'law' is the provision in force as the competent courts have interpreted it." See e.g., Dahlab, supra note 13 at 8 . 24 Supra note 13.
}

independent courts. The Court's task is to determine whether the measures taken at national level were justified in principle that is, whether the reasons adduced to justify them appear "relevant and sufficient" and are proportionate to the legitimate aim pursued. In order to rule on this latter point, the Court must weigh the requirements of the protection of the rights and liberties of others against the conduct of which the applicant stood accused. In exercising its supervisory jurisdiction, the Court must look at the impugned judicial decisions against the background of the case as a whole. ${ }^{25}$

In Dahlab, the Court emphasizes the key point, reiterated in other leading cases, that member states are given a limited but significant "margin of appreciation" to determine whether interferences are necessary in light of legitimate state aims. ${ }^{26}$ Therefore, in considering necessity, the court is attempting to balance some degree of deference to member states with the ECHR's responsibility to uphold fundamental rights and freedoms.

One final dimension of Article 9(2) should be noted. Interestingly, the language of the section refers only to the freedom to manifest one's religion, not to all of the enumerated rights in Article 9(1). ${ }^{27}$ This unique treatment seems to carve out religious expression as a particularly significant area where the state may have greater license to balance competing considerations and justify violations of rights. The controversial issues raised by religious attire have been discussed in two recent cases decided under Article 9.

\section{Şahin v. Turkey}

In a decision of 29 June 2004, the ECHR upheld a ban on Turkish university students wearing the $h i j a b$, the Islamic headscarf. ${ }^{28}$ This

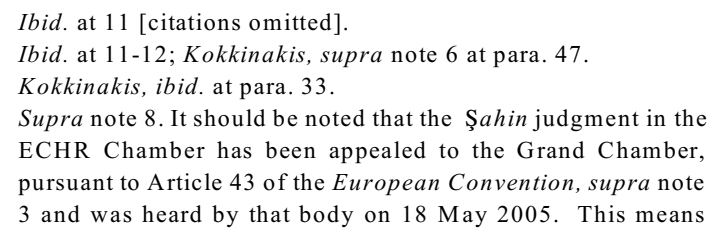


university regulation had been challenged by Leyla Şahin, a medical student at the University of Istanbul, who had worn her headscarf to classes in a desire to show strict adherence to the duties imposed by her faith. In 1998, Şahin was denied admission to an examination because of her apparel. She was later kept out of lectures in the medical school and eventually suspended from the university. ${ }^{29}$ She objected to the exclusion as a violation of her rights to religious belief, practice, and observance, guaranteed under both the Constitution of Turkey and Article 9 of the European Convention.

The practice of wearing the headscarf - or veils, shrouds, or long clothing that completely obscures the body - is not about fashion, aesthetics, or rustic lack of sophistication. In contemporary Turkey, the meaning of such attire is both religious and political. The covered head stands as a "representation of Islamic chastity, the holy past, and Turkish local culture." ${ }^{30}$ Its popularity has surged again in the past two decades in Turkey. Moreover, the matter of headscarves is fraught with political significance. The hijab can be a statement against secular and Western values, which in parts of Turkish society are viewed as corrupting. The scarf itself now has a political life of its own, as part of a politics of identity, capable of serving (to use Jean Baudrillard's language) as an independent signifier. ${ }^{31}$ Debates over whether women should take refuge behind symbols closely allied with Islam and cover their heads, as arguably dictated by the tenets of that faith, ${ }^{32}$ run parallel to the issues of whether Turkish women should share public spaces with men and whether traditional

both that the judgment that we are discussing is not considered a final judgment and that the ECHR has yet to make its ultimate decision. The Grand Chamber judgment has not been released. For details, see the ECHR press release, online: European Court of Human Rights, <http://www.echr.coe.int/Eng/Press/2005/ May/HearingGrandChamberLeylaSahinvTurkey $180505 . \mathrm{htm}>$.

29 M s. Sahin later transferred to the University of Vienna.

30 Yael Navaro-Yashin, Faces of the State: Secularism and Public Life in Turkey (Princeton: Princeton University Press, 2002) at 110 , citing Baudrillard.

31 Ibid. at $110-11$

32 See The Koran, 5 th rev. ed., trans. by N. J. Dawood (London: Penguin, 1990, reprinted 2003) at 248, Surah 24:31, where it is declared "Enjoin believing women to turn their eyes away from temptation and to preserve their chastity; not to display their adornments ...; to draw their veils over their bosoms and not to display their finery ...." sharia law should be restored for the settlement of family disputes. In the words of Marvine Howe, what she calls the "Headscarf War" in Turkey "epitomizes the whole secular-Islamist struggle in this country." 33 Where some commentators characterize the wearing of the headscarf as a sign of subservience (not only to faith, but to patriarchy also), others view it as a mark of self-affirmation that is increasingly adopted by well-educated, forward-looking, working women. ${ }^{34}$

Turkish political struggles over the headscarf and whether it should be prohibited outside of the mosque and private home were intensified by the election in late 1995 of an Islamist political party, Refah, as the leading party in Turkey's parliament. ${ }^{35}$ This prompted what Howe calls a "secular backlash," and in 1997 Turkey's first Islamist prime minister was ousted. ${ }^{36}$ The apparent religious revival of the early 1990 s gave way to a secular revival in the latter part of the decade. The Turkish government reinvigorated its laws against the wearing of headscarves by students and civil servants. Women's groups inside Turkey rallied on occasions where they detected Islamist pressure to repeal those laws. ${ }^{37}$ On the other side, public demonstrations were held by large numbers of Islamist supporters to protest the ban on headscarves ${ }^{38}$ - especially in light of complaints by university students such as Leyla Şahin.

The European Court of Human Rights vindicated the ban on headscarves. The court in Şahin found, first, that the Turkish university regulation constituted an "interference" with the complainant's right to "manifest" her religion through rites or symbols. ${ }^{39}$ Moreover, this interference or violation was "prescribed by law" - for even though Ms Şahin ran afoul of a university regulation, this regulation reflected general Turkish law that made it unconstitutional for students to be compelled to cover their necks

\footnotetext{
Marvine Howe, Turkey Today: A Nation Divided over Islam 's Revival (Boulder: Westview Press, 2000) at 102 [Howe].

$34 \quad$ Ibid. at 227

Ibid. at 228-29.

Ibid. at 124-47.

Ibid. at 244-45.

Ibid. at 280-81.

Supra note 8 at para. 71
} 
with a veil or headscarf for religious reasons. ${ }^{40}$ But the European Court went on to conclude that the interference was justifiable and therefore that the ban was valid. The goal legitimately pursued by the public authorities in Turkey, in making such bans, was to preserve the principle of secularism in that country's public schools and universities. Secularism was treated by the court as "undoubtedly one of the fundamental principles" of the Turkish state. ${ }^{41}$ The court took note that (as in the earlier Dahlab decision) the headscarf in Europe, when worn in an educational setting, conveys an anti-secular message: it is a "powerful external symbol" with a "proselytizing effect," which does not belong in a public school or university. $^{42}$ Furthermore, the court in Şahin questioned whether the Koranic basis for the headscarf was not "hard to reconcile with the principle of gender equality." 43

The court largely accepted the arguments of the Turkish government about the perceived dangers in allowing students to wear headscarves. The primary fear motivating the ban was that fundamentalist students would exert pressure on other Islamist students to conform to a more orthodox version of the faith. Or the pressure might fall on students who belong to another religion or to no religion at all. ${ }^{44}$ Preserving the welfare of students against such "external pressure" - by ensuring the secular nature of public education - is one way to protect freedom of religion. ${ }^{45}$ The court went further than this, and also discerned a connection between secularism and democracy in Turkey. The achievements of the Turkish state in promoting secularism "may be regarded as necessary for the protection of the democratic system in Turkey." 46 The court took judicial notice of the fact that "extremist political movements in Turkey" have arisen which seek to impose religious precepts and symbols on the whole society. ${ }^{47}$ Finally, the court in Şahin justified its decision about the applicability of

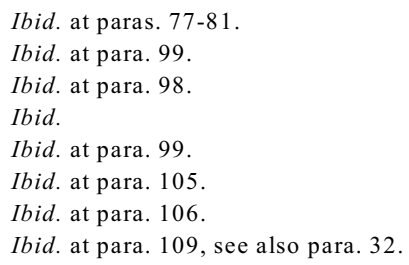

Article 9(2) on the basis of equality. ${ }^{48}$ Women wear the hijab. Although Islamist men often wear beards in deference to their religious convictions, the latter are not compelled to the same extent as headscarves for women. Respect for gender equality provides another ground for concluding that the Turkish ban on headscarves was justified as a necessary interference with the rights contained in Article 9(1) of the European Convention.

In Şahin, the court drew particular attention to Turkey's distinctiveness as a European state. The vast majority of its citizens belong to Islam, ${ }^{49}$ and during the reign of the Ottoman Empire both government and religious groups insisted that people dress according to their religious affiliations. The wearing of fezzes and turbans was not only common, but required. Since the overthrow of that empire in 1923 and the subsequent creation of the Turkish Republic, various constitutional changes have entrenched secularism as a fundamental principle of Turkish public life. Thus, for example, a decree of 1925 banned "all forms of religious dress in public schools, except in Koranic classes." ${ }^{\circ 0}$ The strict separation of religion from politics has been a key feature of the modernization movement in twentieth-century Turkey. That country has increasingly turned its face tow ards Europe, and as Turkey strives for full membership in the European Union, its presence there will change the face of Europe itself.

That the complaint in Şahin was actually taken to the European Court of Human Rights is a bit surprising, since one might suspect that a more promising course for a devout Muslim would be an appeal to religious courts within the faith. Indeed, the European Court responded to the complaint by emphasizing the peculiar history of Turkey, the margin of appreciation that should be accorded to law-makers familiar with local culture and political conditions, and the firmness of

\footnotetext{
Ibid. at paras. 107-11

49 According to recent statistics, more than $99 \%$ of the population of Turkey is Muslim, although the state is officially secular. See: The Europa World Year Book, 5th ed., vol. 2 (London: Europa Publications, 2004) at 4244. See also The World Factbook, online: Central Intelligence Agency <http://www. cia.gov/cia/publications/factbook/geos/tu.html $>$.

50 Howe, supra note 33 at 103.
} 
Turkey's embrace of secularism. Turkey has rejected the fundamentalist political revolutionary movements that have embroiled countries such as Iran in the past quarter-century. The decision of the European Court in Şahin reveals the extent to which Turkey's strategy permits some violations of the right to manifest religious beliefs through potent symbols.

\section{$R$ (on the application of S.B.) $v$. Governors of Denbigh High School}

Another recent decision addressing religious dress in schools and revealing significant points of contrast with Şahin is the March 2005 decision of the English Court of Appeal in $R$ (on the application of $S B$ ) v. Governors of Denbigh High School. ${ }^{51}$ The U.K. remains relatively homogeneous with respect to religion. The country is more culturally diverse than ever before, but a Christian majority representing approximately $72 \%$ of the population remains. ${ }^{52}$ In contrast, Muslims are a clear minority, although at $2.7 \%$ of the population, they constitute the second largest religious group. ${ }^{53}$ It should be noted that the Muslim community in the U.K. is not uniform; rather, it is divided both along ethnic lines (including Pakistani, Bangladeshi, and Black African Muslims) and by degree of traditionalism or activism (there is an "extremist fringe" but most Muslims are more politically moderate and likely to accept both Islamic and secular values in law). ${ }^{54}$

Also, the U.K. (unlike France or Turkey) does

${ }^{51} \quad R$ (on the application of $S B$ ) v. Governors of Denbigh High School, [2005] 2 All E.R. 396, 1 F.C.R. 530, [2005] EWCA Civ 199, online: BAILII <http://www.bailii.org/cgi-bin/markup. cgi? doc $=$ ew $/$ cases $/$ EW CA $/$ Civ $/ 2005 / 199 . h$ tml\& query $=\% 22 \mathrm{~g}$ overnors $\% 20$ of $\% 20$ denbigh $\% 20$ high $\% 20$ school $\% 22>$ [Denbigh].

52 Office of National Statistics, "Religion in Britain: Census Shows $72 \%$ identify as Christians," online: $<$ http://www.statistics.gov.uk/cci/nugget.asp?id=293> ["Religion in Britain].

53 Ibid. It should be noted that Islam is the second largest religious group only when respondents declaring "no religion"/"religion not stated" are excluded; this group (at $23.2 \%$ of responses) outnumbers Muslims.

54 Office of National Statistics, "Religion: 7 in 10 identify as White Christian," online: Office of National Statistics $<$ http://www.statistics.gov.uk/CCI/nugget.asp?ID=460\&Pos= $1 \&$ ColRank=1\&Rank=326>; John Rex, "Islam in the United Kingdom" in Islam, Europe's Second Religion: The New Social, Cultural and Political Landscape, ed. by Shireen T. Hunter (Westport: Center for Strategic and International Studies, 2002) 51 at $58,60,73$. not emphasize secularism in education, but rather, endorses a strong presence of religion in schools. Notably, legislation requires religious education and acts of collective worship in every school, subject to some exceptions, variations between schools, and parents retaining the right to withdraw their children from religious activities. ${ }^{55}$ However, the U.K. government also recognizes a need for cultural sensitivity and accommodation in schools and their dress codes, as evidenced in circulars released by the Department for Education and Science. ${ }^{56}$

It was in this context that the English Court of Appeals decided the Denbigh case. The claimant, Shabina Begum, attended a community school with a dress code developed in consultation with the community (including Muslim groups) and viewed by the school as essential to its goals (achieving high educational standards and creating an environment conducive to community and learning for a multicultural student body).$^{57}$ This dress code permitted, among other options, wearing the shalwar kameeze (a form of Islamic dress consisting basically of a tunic and pants), with or without a headscarf. ${ }^{58}$ Begum wore the shalwar kameeze for two years at school, then decided that it was no longer an adequate form of religious dress and that she should wear the jilbab (a form of dress covering the body more completely than the shalwar kameeze and obscuring the shape of the body). ${ }^{59}$ The school took the position that Begum could not attend school unless she complied with the dress code (which the jilbab did not). ${ }^{60}$ An impasse was reached, resulting in Begum's absence from school for almost two years and, ultimately, to an application for judicial review in the English courts based on an alleged denial of religious rights guaranteed under Article 9 of the European

\footnotetext{
55 School Standards and Framework Act 1998 (U.K.), 1998, c. 31, ss. 69, 70, 71, Schedule 19, 20; Education Act 2002 (U.K.), 2002, c. 32, ss. 80(1)(a), 101(1)(a); see also UK: The Official Yearbook of the United Kingdom of Great Britain and Northern Ireland (London: The Stationery Office, 2001) at 233.

56 Denbigh, supra note 51 at paras 21-23.

57 Ibid. at paras. 1, 4. Interestingly, the school was roughly $79 \%$ Muslim, had been recognized for achievement of ethnic minorities, and emphasized accommodation of minority groups insofar as compatible with providing an environment conducive to living and learning for all students.

$58 \quad$ Ibid. at paras. 5-7.

$59 \quad$ Ibid. at paras. 8,14 .

${ }^{60} \quad$ Ibid. at paras. 15-16.
} 


\section{Convention}

At first instance, Begum's application was dismissed, essentially on the basis that the school had merely insisted on adherence to their dress code without discriminating or intending to prevent Begum from attending school. ${ }^{61}$ The Court of Appeal unanimously reversed the decision below (in three separate concurring judgments), holding that Begum had indeed been excluded from school based on an unjustifiable violation of Article $9 .^{62}$

An emphasis on procedure was at the heart of all three judgments, reflecting that the Court's main concern was neither with the fact nor the substance of the ban on religious forms of dress, but rather, with a lack of process on the school's part. ${ }^{63}$ The Court, per Brooke LJ, found a violation of Article 9(1) relatively easily ${ }^{64}$ and proceeded to focus on potential justifications. In considering the elements of Article 9(2) the Court found that the dress code was prescribed by law ${ }^{65}$ but never came to a conclusion on the necessity of the substance of the ban. Instead, the Court held that the necessity of measures dealing with religious rights is context-specific and depends largely on the question of whether or not the school (or other government body) came to its decision in a procedurally correct manner.

Interestingly, the Court established a positive onus on schools (and by analogy, likely other

${ }^{61} \quad$ Ibid. at para 23; see also $R$ (Begum) v. Headteacher and Governors of Denbigh High School, [2004] ELR 374, [2004] EWHC 1389 (Admin) (Q.B.), online: BAILII < http://www. bailii.org/ew/cases/EW HC/Admin/2004/1389.html>

62 Supra note 51 at para 78 . By way of remedy, the court granted declarations that the school unlawfully excluded the claimant, unlawfully denied her the right to manifest her religion, and unlawfully denied her access to education. There is no indication at this time that the case will proceed to the House of Lords.

63 This provoked criticism by the school, reported in the British press, that they had lost on a "technicality." However, others, including some Muslim groups, took a different position and praised the approach as reflective of common sense. For discussion, see "Schoolgirl wins Muslim gown case" $B B C$ News, UK Edition (2 March 2005), online: $<$ http://news.bbc.co.uk/1/hi/england/beds/bucks/herts/4310545. stm>. Another newsworthy aspect of Denbigh was the involvement of Cherie Booth Q.C., the prominent barrister married to Prime Minister Tony Blair. Booth represented the claimant Begum in her successful appeal.

64 Supra note 51 at para. 49.

65 Ibid. at para. 61. government bodies) to follow a prescribed decision-making process before limiting religious rights. Broadly, this onus has the effect of requiring government bodies to consider a number of factors before a valid limitation on religious rights can be established. These considerations appear to largely mirror the issues that a court would consider in assessing an Article 9 claim and include: religious rights at stake, any potential violations of these rights, and the possible justifications for any violations. ${ }^{66}$ As the Court points out, this approach leaves considerable room for schools (and other bodies) to regulate religious attire, provided that they first give due weight to religious rights and properly assess potential justifications for limiting these rights. ${ }^{67}$ The approach also leaves some degree of uncertainty, which the Court suggested that the government should remedy by providing schools with additional guidance so that additional litigation using up scarce resources and time of school boards would not be required. ${ }^{68}$

Applying this approach to the facts in Denbigh, the Court held that the proper decisionmaking process was not followed and, therefore, that the school's actions unjustifiably limited the claimant's religious rights. Despite the Court's

${ }^{66} \quad$ Ibid. at para. 75 ; see also para. 81 for additional considerations deemed relevant in this particular case. Specifically, the decision-making process prescribed by the court (at para. 75) was as follows:

(1) Has the claimant established that she has a relevant Convention right which qualifies for protection under article 9(1)? (2) Subject to any justification that is established under article 9(2), has that Convention right been violated? (3) Was the interference with her Convention right prescribed by law in the convention sense of that expression? (4) Did the interference have a legitimate arm [aim]? (5) What are the considerations that need to be balanced against each other when determining whether the interference was necessary in a democratic society for the purpose of achieving that aim? (6) Was the interference justified under article $9(2)$ ?

It seems that this process must be applied by the decision-maker at the time of the decision, unlike the Canadian constitutional law approach allowing for justification of limitations on rights after the fact.

67 Indeed, the Court states that restrictions on religious freedoms could be justified under the prescribed decision-making process, even if substantively similar to the impugned actions of Denbigh. See Ibid. at para. 81 (per Brooke LJ), para. 87 (per Mummery LJ), para. 92 (per Scott Baker LJ).

68 Ibid. at para. 82 (per Brooke LJ), para. 89 (per Mummery LJ). 
sympathy for schools dealing with complex issues surrounding religion and law and the possibility that the actions of the school were justifiable with reference to the considerations in Article 9, the school was not entitled to resist Begum's claims because "it approached the issues in this case from an entirely wrong direction and did not attribute to the claimant's beliefs the weight they deserved." 69

It is also worth noting the reasoning of the Court concerning the significant diversity between and among groups all subject to the same rights under the European Convention. Firstly, the Court emphasized testimony alluding to divisions within Islam, particularly on the issue of appropriate religious dress. ${ }^{70}$ The main concern was that this intra-group diversity could lead to social pressure on some Muslims and conflicts between individual and group rights, suggesting a potential need for measures to counter pressure imposed on more "liberal" Muslims by those taking a more "strict" view. ${ }^{71}$ These issues were viewed as important in potential justification of dress codes, and also interestingly raise the possibility that restrictions on religious dress could promote, rather than inhibit, religious freedom of some people.

Secondly, the Court noted significant differences among European countries, including the extent of secularism, demographic considerations (especially the prevalence of Islam), and variations in political context (particularly the pervasiveness of extremist religious movements). The Court stated that context is "all-important," 72 suggesting that different conceptions of religious rights and, indeed, different limitations on religious rights may be justifiable in different contexts. ${ }^{73}$ More

Ibid. at para. 78 .

Ibid. at paras. 51-57.

71 The Court placed considerable weight on its choice of terminology used to refer to various groups within Islam, denouncing the term "fundamentalist" because of negative connotations inappropriate in this context and choosing instead to refer to "strict" Muslims (meaning those Muslims who believe the jilbab is mandatory dress for Muslim women) and more "liberal" Muslims (meaning those Muslims who consider the shalwar kameeze to be adequate religious dress for a Muslim woman). See Ibid. at para. 31 .

Ibid. at para. 72 .

73 Ibid. It is worth noting Brooke LJ's statement that "there are clearly potential tensions between the rights and freedoms set out in a Convention agreed to more than 50 years ago between Western European countries which on the whole adhered to specifically, the Court focused on the contrast between Turkey and the U.K., emphasizing that the U.K. is not a secular state and does not face the same political pressures as Turkey. ${ }^{74}$

Generally, the Court's discussion of intergroup and intra-group diversity within Europe makes it clear that any conception of common rights, universally applicable to all people subject to the European Convention regardless of context, is significantly complicated, even undermined, by divisions within and between groups.

\section{FRENCH LAW ON RELIGIOUS SYMBOLS IN SCHOOLS}

Although the largest part of the French population belongs to the Roman Catholic church, Islam has become more of a presence in the past forty years. According to 2001 statistics, about five million Islamic adherents reside in France, making up roughly $8 \%$ of the total population of the country. ${ }^{75}$ Islam has displaced Protestantism and Judaism as the largest religious minority in France.

The law adopted by the French government in March 2004 amended the Code of Education to regulate the wearing of religious symbols in the following terms:

Art. L. 141-5-1. In schools, colleges and public lycées, the wearing of signs or attire by which students conspicuously manifest religious membership is prohibited. $^{76}$

Previous regulations prohibiting religious propaganda, proselytism, and pressures in schools had been adopted in 1989. But they did not go so far as to prohibit outright the wearing of religious

Judaeo-Christian traditions, and some of the tenets of the Islamic faith that relate to the position of women in society." Interestingly, Brooke LJ felt compelled to make this point despite the fact that the issue was not addressed in argument. 74 Ibid. at paras. 65-73, especially paras. 72-73.

75 See Europa World Book, supra note 49, vol. I at 1673, 1694.

76 Loi $n^{\circ} 2004-228$ du 15 mars 2004 encadrant, en application du principe de laïcité, le port de signes ou de tenues manifestant une appartenance religieuse dans les écoles, collèges et lycées publics, J.O. no. 65, 17 March 2004 at 5190, online: Legifrance $<$ http://www.legifrance.gouv.fr/W Aspad/UnTexteDeJorf?nu mjo=MENX0400001L $>$ [translated by authors]. 
symbols. The regulations were loosely framed and they proved difficult to implement. The main complaint was that educational administrators, who were responsible for administering the law, had difficulty interpreting and applying the law in individual instances, which were supposed to be handled on a case-by-case basis. It was almost impossible to draw appropriate lines.

The 2004 law was not enacted in a vacuum. Before prohibiting public school students from wearing conspicuous religious symbols, the French government commissioned an independent study on whether such apparel was compatible with French national values and principles. The independent commission, created in July 2003, was chaired by Bernard Stasi, a former politician who since 1998 had occupied the post of "Mediator of the Republic," or national ombudsman for France. The eighteen other members of this special panel represented a broad array of backgrounds. ${ }^{77}$ The Stasi Commission was charged by President Chirac to investigate how the principle of laïcité applies in the contexts of employment, provision of public services, and most importantly, French schools. We have left the key word laïcité untranslated, for it has connotations different from the word "secularism." In its final report, delivered in December 2003, ${ }^{78}$ the Stasi Commission itself recognized that, while the rest of Europe prefers to use "secularization" to denote the process of separating religion from politics, in France the most precise and accurate words for capturing the relevant concept are laïcité and its cognates, such as laïser and lä̈que (or lä̈c). ${ }^{79}$

The Commission held extensive public consultations. A wide variety of religious, political, philosophical, and social opinion was canvassed during these hearings. The Commission

77 For profiles of the commission members, see the following comprehensive report: "Le Rapport de la Commission Stasi sur la Laïcité" Le Monde (12 December 2003), online: $<$ http://medias.lemonde.fr/medias/pdf_obj/rapport_stasi_111 203.pdf>.

78 See France, Commission de reflexion sur l'application du principe de laïcité dans la République, Rapport au Président de la République (11 December 2003) [Stasi Commission Report], online: La documentation Française <http://www. ladocumentationfrancaise.fr/rapports-publics/034000725/ index.shtml $>$ [translated by authors]

79 Ibid. at 20 went so far as to hold meetings with students from a number of lycées and collèges to gain first-hand testimony from students who could be affected by any recommendations that the Commission might make. ${ }^{80}$ While the raison d'etre of the Commission was to respond to public concerns and controversies over the application of laïcité in contemporary institutions, its sole focus was not on the wearing of Islamic scarves in French public schools. Behind this well-publicized issue lay broader and more troubling questions: about the integration of immigrants, about rising unemployment levels, about discrimination, and about the presence and influence of (unidentified) political extremists. ${ }^{81}$

The product of the Commission's work was a florid description and elaboration of laïcité as the "cornerstone" of the French republic since the Revolution of 1789. It is not a mere incidental feature of French governmental structures, but instead it is (in the Commission's words) "constitutive of our collective history." 82 The principle that the churches shall not interfere in public political life, and that the state has no business regulating religious convictions has traditionally embraced three values. These include: freedom of conscience; the equality of all religions before French law; and state neutrality on matters of religious belief. ${ }^{83}$ The political domain should be strictly separated from the religious sphere - the state shall neither require citizens to obey certain beliefs, nor forbid this. To

\footnotetext{
For a list, see ibid. at 5 .

81 See ibid. at 6-7, and especially the Commission's observation at 7 that: "As we ought to be clear: yes, some extremist groups in our country are working to test the Republic's resistance and to pressure some youths to reject France and its values" ["Car il faut être lucides: oui, des groupes extrémistes sont à l'oeuvre dans notre pays pour tester la résistance de la République et pour pousser certains jeunes à rejeter la France et ses valeurs"] [translated by authors]. See also ibid. at 44, where the Commission refers to a "permanent guerilla war against laïcité." Disquiet about these aspects of French social life were borne out in the recent upheavals, not only in Paris suburbs but in many cities throughout France, where thousands of cars were burned and youths battled police, leading to the national government to take unusual steps in November 2005. First, it declared a state of emergency. Second, it discussed a package of social and economic reforms aimed at alleviating racial discrimination and unemployment. See Mark Landler, "French State of Emergency" International Herald Tribune ( 9 November 2005), online: <http:www.iht.com/articles/2005/ 11/08/news/france.php>.

$82 \quad$ Ibid. at 10 .

83 Ibid. at 9.
} 
these traditional facets, the Commission added one more value associated with laïcité: the value of gender equality, which has become a fundamental value of the French republic in more recent decades. Under the principle of laïcité, the government has a duty to protect all children against sexist discrimination that might result from religious bigotry. ${ }^{84}$

The Stasi Commission devoted part of its report to France's obligations in light of Article 9 of the European Convention. This section of the report anticipates squarely the analytical guidelines laid down by European courts in determining whether a law that infringes religious freedom is nevertheless justified by arguments of necessity ${ }^{85}$ To a large extent, if the French law is tested in the future by a judicial challenge, the Stasi Commission's rationale for banning religious symbols in schools would form an important background to the government's defence of the law as valid. The Commission's discussion repeatedly emphasizes the need for "tranquillity" or "serenity" in classrooms, if educational goals are to be achieved ${ }^{86}$ Central among these goals is the formation of students into "enlightened citizens." ${ }^{" 87}$ To cultivate the aim of "awakening a critical conscience," sources of conflict or disorder should be removed from the school setting. ${ }^{88}$ In the words of the Commission, the state has a duty to protect and insulate students against la fureur $d u$ monde - the passions of the external world. ${ }^{89}$ The Commission concludes by recommending that laïcité itself become the subject of civic instruction in the public schools - this could be tied in with a day celebrating Marianne, the ubiquitous national icon of the French republic. ${ }^{90}$

\section{CONCLUSIONS}

Recent European developments relating to religious attire worn in an educational setting reveal some significant trends. The interpretation of Article 9 across Europe, whether the decision is

\footnotetext{
Ibid. at 29, 46 .

Ibid. at 20-21.

Ibid. at 41 .

Ibid. at 56 .

Ibid. at 57 .

Ibid. at 56 .

Ibid. at 66 .
}

made by the ECHR or the court of an individual member state, is highly sensitive to local conditions regarding history, social, and political context; the values of member states; and the particular series of events through which an impugned measure came into being. Although individual choices and rights play an important part in the decisions of legislators and courts, it seems that their primary focus is elsewhere. Courts and legislators work from certain premises about the cultural meaning of religious symbols and the current social and demographic circumstances in the state under consideration. The law-makers and courts do not focus primarily on individual choice or conscience, and indeed, they might not even inquire into the motivations of a particular individual affected by the law.

Therefore, insofar as a theme can be extracted from recent developments, it might well be that of a considered (although by no means unlimited) appreciation of increasing pluralism in Europe and the consequent need to allow states some room to balance values insofar as they can do so in a manner consistent with human rights. At the same time, courts seem to be trying to deal with both positive and negative elements of cultural and religious realities in member states, including practical or symbolic effects of religious attire, suggesting that some appropriate limitations on more harmful elements of certain religions may be justifiable, indeed, commendable, in the continuing attempt to make pluralism work within the scope of an established liberal human rights scheme.

However, the existence of a set of general trends arising from cases and legislative developments does not imply a comprehensive or settled approach to bans on religious attire in Europe. Rather, the debate in this area persists, so that developments thus far reveal at least as many interesting questions as they do answers. How and why do courts use the margin of appreciation as they do in according states varying degrees of latitude to balance religious and other values? To what extent are courts reflecting tolerance of diversity (and particularly of the Islamic fact) in European states? How important is it that these cases have taken place in schools, where students, rather than full political subjects, are involved and where difference of opinion provides the data for 
critical judgment? How do these recent debates over headscarves and other religious attire relate to ongoing feminist debates surrounding diversity and gender equality? ${ }^{91}$

One question stands out as particularly important in debates over recent cases and legislation in Europe: what is secularism? This question can be divided into two separate inquiries: what is the meaning of secularism from a descriptive point of view and how is secularism viewed normatively? Neither is easily answered.

From a descriptive standpoint, the only clear answer to be drawn from the debate (in cases, legislation, and the public sphere) is that there is no widely accepted meaning of secularism. ${ }^{92}$ Rather, the European understanding of secularism varies both between and within member states. For some, the term connotes values essential to a good society, including: modernity, liberal democracy, equality, a free marketplace of ideas conducive to human flourishing, and an absence of coercion. For others, conversely, the term is associated with stifling of religious beliefs, suppression of diversity, or, indeed, religious oppression. For still others who deny the possibility of creating a political space free of spiritual values, secularism is itself a form of state-endorsed religion or ideal. ${ }^{93}$ Further, the cases reveal that secularism carries different meanings in different countries. In Turkey, secularism is understood as instrumental to achieving modernity, as a bulwark against slipping back into feudalism. In France, laïcité seems to be understood less instrumentally and more in terms of passion and inherent value; indeed, the principle is completely tied up with national identity and self-conception as well as civic instruction. ${ }^{94}$ In the U.K., secularism is neither the reality in society nor a goal of the state.

91 See Burçak Keskin-Kozat, "Entangled in Secular Nationalism, Feminism and Islamism: The Life of Konca Kuris" (2003) 15:2 Cultural Dynamics 183, online: <http:cdy.sagepub.com/cgi/ content/refs $115 / 2 / 183>$.

92 For discussion of the multiplicity of meanings of secularism, even at the time when the term originated, see Peter Gay, The Party of Humanity: Essays in the French Enlightenment (New York: Norton \& Company, 1959) at 121.

93 For discussion of the claim that secularism is itself a form of religion, see: Kent Greenawalt, Does God Belong in Public Schools? (Princeton: Princeton University Press, 2005) at 81 82.

94 This is reflected in the Stasi Commission Report, supra note 78 at 66
The U.K. (particularly the English court in Denbigh) emphasizes values that other states might see as related to secularism such as equality, non-discrimination, procedural fairness, respect for pluralism, and the need for state protection against coercion and extremism. However, England's position appears to be that these values are separate from secularism, and indeed, possible in a non-secular state.

From a normative dimension, the key issue is as follows: how ought secularism to be understood and embodied? One important subsidiary question is whether secularism is itself anti-religious. According to the recent cases that we have examined, it would seem not. In fact the cases suggest the converse, namely that secular ideals and the separation between church and state are meant to preserve religions against political interference as much they are intended to preserve the political sphere from religious intrusion. Judges and legislators in this context are not being anti-religious, but rather, are attempting to protect individuals, religions, and rights alike by reining in fundamentalist varieties of religious belief that seek to impose their precepts or practices in the public sphere - especially in a context where students are vulnerable to pressure, where the state owes students a protective obligation, and where critical capacities of students are supposed to be nurtured. Secularism and secular values are understood as protective of fundamental values, including religion, not opposed to them.

Given that this appears to be the conception of secularism endorsed by European courts, the final question is whether such a conception of secularism is defensible from a liberal point of view. Again, the answer is not easy. In order to appreciate the question, it should be situated within broader debates about the role of religion and multiculturalism. Generally, there are two schools of thought. Each values both core liberal ideals (including rights) and accommodation of cultural and religious difference, but recognizes that it is difficult to achieve both of these at the same time. Therefore, the divergence between the two schools is largely a debate over which values ought to be given paramount importance.

Some theorists advocate widespread acceptance of diversity as a crucially important 
principle, which implies that secularism and any principles and policies based thereupon ought to be subject to adjustment to accommodate a wide range of cultural, ethnic and religious diversity. From this perspective, it seems that secularism ought to give way to multiculturalism and accommodation, at least to some extent, although it should be noted that theorists differ significantly among themselves as to the preferable degree of accommodation (and conversely, of limitations on accommodation based on context and other, often liberal, values).$^{95} \mathrm{~A}$ subgroup of theorists within this school would likely argue that those European authorities seriously concerned about difficulties in integration of minorities are not going far enough to accommodate the cultural and religious diversity of Muslims, while others might favour contextual justifications for the particular limitations in the way that some European courts have done. ${ }^{96}$

Other theorists argue that a core of liberal, democratic, and egalitarian values are of paramount importance to the good liberal state, so that recognition of difference, while crucially important, should be limited to the extent that it undermines these central political values. In other words, while accommodation to cultural difference is desirable (even necessary), elements of cultures or religions that are oppressive or

95 For a leading liberal theory of multiculturalism, see Will Kymlicka, Multicultural Citizenship: A Liberal Theory of Minority Rights (Oxford: Clarendon Press, 1995). Kymlicka deals specifically with religious symbols and attire at 114-15, 177. He argues that recognition of symbols and attire could be beneficial as they promote inclusion, but also seems at times to be sympathetic to dress codes. Based on his comments in this work, it is not clear entirely what position Kymlicka would take on recent bans in Europe, although it is clear that, on his account, recognition of cultural difference should be accepted only insofar as compatible with core liberal values (this argument is summarized at 126).

96 For a range of views on these sorts of questions, see the responses in Part 2 of Joshua Cohen, Matthew Howard \& Martha C. Nussbaum, eds., Is Multiculturalism Bad for Women? Susan Moller Okin with Respondents (Princeton: Princeton University Press, 1999) at 27-105 [Okin]. There is some discussion of headscarves specifically in some of the enclosed essays: see Bhiku Parekh's "A Varied Moral World" in Okin 69 at 71, 73 (which would seem to be consistent with opposition to bans on headscarves) and Will Kymlicka's "Liberal Complacencies" 31. These two essays reflect the considerable contrast between theorists all grappling with the concept of multiculturalism: Kymlicka situates multiculturalism within a liberal framework (and sees this as beneficial), whereas Parekh argues that liberal values are, at least, not self-evident, and indeed that it may be another form of fundamentalism to impose liberal values on cultural minorities. dangerous ought not to be accepted in the name of multicultural accommodation. From this standpoint, it would seem that the range of approaches to secularism developed in European courts is defensible. For example, the conceptions advanced seem consistent with John Rawls' arguments that pluralism, although a fact of political life, should be limited so as to ensure consistency with basic political values of justice and to avoid fundamentalism inimical to these values. ${ }^{97}$ These views also seems to accord with the arguments of Susan Moller Okin that multiculturalism and accommodation of cultural difference may (and indeed should) be limited insofar as this is necessary to prevent the oppression of minority groups.$^{98}$ On balance, then, it would seem that the approaches taken by of European courts to secularism are supported significantly, if not to an unqualified extent, by liberal theory.

Those developments in European law discussed above illustrate how courts, legislatures, religious bodies, and public opinion have contributed to a lively debate that, although focussed on regulations regarding students, resonates far beyond school precincts. To a large degree, though the debate is about symbols, the underlying tensions arise from troubling, underlying social conditions. In this new Europe, confronted by serious difficulties in integrating of new minorities, legislators and policy-makers must interpret both their own constitutional duties, and also the constitutional limitations on their powers. The controversy in some countries over manifesting one's religious beliefs, especially in a way that fundamentally challenges national values or aspirations - i.e., that could be viewed as going so far as to undermine those values - has prompted legislators to draw lines that might

See John Rawls, Political Liberalism (New York: Columbia University Press, 1993); and "Commonweal Interview with John Rawls" in Samuel Freeman, ed., John Rawls: Collected Papers, (Cambridge: Harvard University Press, 1999) 616. In the latter piece, Rawls provides more recent commentary on his treatment of religion and the state. Interestingly, he denies the claim that he is really arguing for secularism, instead, reiterating his main argument that any religious doctrine can appropriately be introduced into political liberalism, provided that it is consistent with core values of political justice and supported by public reasons.

98 See Okin, supra note 96. For another critique of multiculturalism that seems sympathetic to Okin's point of view, see Wikan, supra note 2 at 146, 156. 
surprise observers used to Canada's multicultural climate. After more than two centuries of experience with philosophical movements of Enlightenment, the relations between state and religion in Europe remain complex, checkered, and uneasy.

\section{Richard W. Bauman}

Professor

Faculty of Law, University of Alberta

Chair, Centre for Constitutional Studies Management Board

rbauman@law.ualberta.ca

\section{Sarah L.M. Weingarten}

Third-Year LL.B. student

University of Alberta 